\section{VOLUNTEERING OF CZECH COLLEGE STUDENTS - EXPERIENCE AND MOTIVATION}

\begin{abstract}
Volunteering is an activity that enables the development of an individual's competency and is also an area of interest both of society and the academic community. This article aims to compare the motivation for volunteering and the experience of volunteering with students within helping professions and economics. For the purpose of this research, a questionnaire about volunteering was compiled. The article presents the research results into volunteering of Czech students of economic and non-economic study programmes of the College of Polytechnics Jihlava $(n=282)$. According to the results, the field of study and the frequency of volunteering depend on each other. Students' gender and the frequency of volunteering do not depend on each other; neither do the study field and the volunteering experience. The biggest motivations for volunteering are feeling useful, gaining new experience and skills. On the other hand, the lack of time and information (ignorance) are perceived as limitations. The study provides an opportunity for developing more guidelines in promoting volunteering activities within the young population and society as a whole.
\end{abstract}

\section{KEYWORDS}

College, experience, motivation, research, students, volunteering

\section{HOW TO CITE}

Činčalová S., Černá M. (2021) 'Volunteering of Czech College Students - Experience and Motivation', Journal on Efficiency and Responsibility in Education and Science, vol. 14, no. 2, pp. 79-88. http://dx.doi.org/10.7160/eriesj.2021.140202

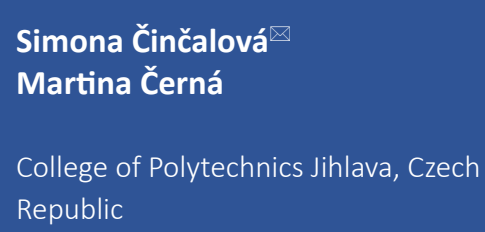

simona.cincalova@vspj.cz

\title{
Highlights
}

- The field of study and volunteering experience do not depend on each other, but there is dependence between the field of study and volunteering frequency.

- Students' gender and the frequency of volunteering do not depend on each other; neither do the study field and the volunteering experience.

- There is a lack of information for students about volunteering; a system needs to be implemented.

\section{INTRODUCTION}

Volunteering is a freely chosen activity, performed for the benefit of others without the right to remuneration. The current situation of volunteering in the Czech Republic is as problematic as in other post-communist countries, where volunteering was devalued in the second half of the twentieth century. After the regime change, there was a relatively rapid increase in the interest in both volunteers and volunteering in various fields, including social.

Each of us can probably define the concept of volunteering, a volunteer and voluntary activity in our own way. The idea of volunteering does not have a uniform definition in the literature. The essence of volunteering is relatively easy to define. The big problems are identifying the boundaries where volunteering ends and where it begins. The individual authors do not agree, for example, on whether or not to include an individual who performs voluntary activities for their immediate surroundings as a volunteer (Haski-Leventhal et al., 2019; Savitz et al., 2008; Rochester et al., 2010). The same attitude to the definition of volunteering can be seen in the context of volunteering performance. It is always of personal volition and without the right to remuneration. By volunteering, Pospíšilová, Frič and Tošner (2011) mean unpaid work for people beyond the family and close friends which is also for the benefit of the surrounding environment. The work is considered unpaid even when expenses are reimbursed, or a symbolic reward is given. According to Lockstone-Binney et al. (2010), volunteers and volunteering contribute to communities in most countries and cultures. They are of widespread importance to leisure because volunteers constitute a significant component within the sector's workforce in various roles and contexts. Both individual and structural determinants must be taken into account when 
considering volunteering. It means that attitudes and motives significantly affect volunteering. But significant differences among population groups are noticed, e. g. wealthy individuals are three times more recruited (Musick and Wilson, 2008).

There are many different studies on students' volunteering (e.g., Cunha, Mensing and Benneworth, 2019; Power, Boughen and Ames, 2019; Kogan and Kvon, 2019 or González et al., 2019). Febriani and Selamet (2020) ask if the brand image makes a difference in college students' intention to volunteer for non-profit organisations. The results indicate the importance of the brand image in increasing volunteering intention. This fact can inform Nurse Practitioners of Oregon (NPO) about the necessity to create better strategies to recruit volunteers. Schech et al. (2020) describe how international volunteerism contributes to progress processes of endogenous capacity in non-profit organisations.

Motivations for volunteering can be various (Shier, LarsenHalikowski and Gouthro, 2020). Lockstone-Binney et al. (2010) emphasise the interdisciplinary perspective which means economic, psychological and sociological aspects. Berei (2020) analyses the characteristic of volunteering and student's motivations. The conclusions present traditional students' motivations such as helping others, relational and self-development intentions, and global motivational factors like learning new languages and discovering new cultures. The results of the research of Moore, Warta and Erichsen (2014) show that the strongest motives for volunteering are values (altruistic volunteering) and understanding (new learning experience). The most common volunteer work in organisations focused on health and wellness, serving children or delivering education and reducing poverty. Shye (2010) does not ask what motivates volunteers, but to what extent volunteering rewards an individual. Haski-Leventhal et al. (2020) point out that volunteering has benefits for students as well as for universities and colleges. Mitic (2020) finds out that volunteering and studying abroad represent an educational experience that promotes democratic outcomes. Volunteering is also a form of moral engagement in which young people engender a sense of duty and responsibility for others.

Navickas, Simkus and Strunz (2016) claim that volunteering has a positive impact on students' life quality. Volunteering can help young people control their stress, build their independence, win other acquaintances, find new friends, improve their communication skills and teamwork, win work experience and reduce awareness of new tasks and situations. Volunteering can contribute to students' employability due to new experiences and its benefits in terms of job opportunities. According to Moreno (2013), social factors (connecting to the family, school, community) positively affect young people's health. Volunteering can be one way to improve community ties, gain valuable life experiences, and feel valued and important. Khasanzyanova (2017) writes that volunteering benefits both personal and professional development. Volunteering also has health benefits such as increasing positive emotions, reducing depression, lowering cholesterol levels, blood pressure, and body mass index.

According to Wilson (2000), volunteers become more often young people who have parents with volunteering experience.
These people usually have higher education and socioeconomic status and are more often believers. Young people are dedicated to volunteering during their puberty. Declining trends appear between adolescence and early adulthood. Then interest in volunteering grows again and peaks at middle age. Osoba (2017) writes that college alumni are significantly more engaged (not only in volunteering but also donating, attending a public hearing on a local issue or signing a petition) than people with primary or secondary education. And individuals in their thirties are more engaged than young people under 24 (in this research it means at least one action in public interest over the past five years). Involved people are more satisfied. According to Bierhoff (2006), long-term voluntary activity is influenced more by the individual's personality characteristics than spontaneous short one-time help. Bierhoff (2006) and Křivohlavý (2003) state that prosocial behaviour is based primarily on empathy, social responsibility, the idea of a just world, an internal locus of control and self-efficacy. Besides, it is formed by other factors, especially the helper's person and personality, the social environment, situational factors, and the person and the character of the recipient of prosocial behaviour. It is also proven that good mood and weather have a positive effect on prosocial behaviour. The influence of a negative mood on prosocial behaviour is not entirely clear. It cannot be said this is a wrong matter, e.g., a feeling of guilt or sadness strengthens the willingness to help.

The article aims to compare the motivation for volunteering and volunteering experience with students of helping professions and economics. Understanding the motivations for volunteering is very important because it determines the levels and types of support we provide them. Students of helping professions are supposed to be more engaged in volunteering (due to more opportunities) than students of economics. Our interest is to confirm or refute this myth. The theoretical background was discussed. The following sections will present materials and research methods, results, discussion and conclusion.

\section{MATERIALS AND METHODS Sample}

The survey on student volunteering took place among the students of the College of Polytechnics Jihlava in the winter semester of the academic year 2019/2020 (before the crisis caused by COVID-19). A questionnaire was filled in by 183 students of economics (the study programmes - Finance and Management, Travel and Tourism) and by 99 students of helping professions (the study programmes - Clinical Social Worker, General Nurse, and Midwifery). The College of Polytechnics Jihlava is the only tertiary education institution in the Vysočina Region, the Czech Republic. It offers accredited Bachelor's study programmes and follow-up Master's programmes. Nearly 2000 full-time and part-time students are enrolled in the programmes at present. The study programmes provide a well-balanced combination of theoretical knowledge and practical skills following the needs of the regional labour market. As the name "polytechnics" suggests, this college offers a bright range of study programmes. Volunteering and social responsibility of students and academic workers are an 
essential part of the college culture. Volunteering is a topic of a long-term multidisciplinary academic research. Work activities of assisting professionals are oriented on material, financial, informational, cognitive or emotional benefits of clients. The work quality depends not only on the theoretical knowledge, experience, and qualification of the worker, but also on the structure of the personality and prosocial behaviour (Mlčák, 2010).

In a questionnaire, we ask about students' gender, the study programme, and their volunteering experience (how often they volunteer, what motivates them, and when they started volunteering). In the case of no experience, we ask about the reason and if they are considering involvement in volunteer activities. (See the questionnaire in Appendix).

Following research hypotheses and research questions are the subject to verification:

- H1: There is no relationship between students' study program and their volunteering.

- H2: There is no relationship between college students' study programme and their volunteering frequency.

- H3: The gender of students and their volunteering frequency do not depend on each other.

- RQ1: What is the most frequently mentioned motivation for student volunteer activities?

- RQ2: What is the most significant limitation for student volunteer activities?

\section{Chi-Square test}

To meet the aim of the article, the basic test for determining the interdependence of two categorical variables, the chi-square test of independence, was chosen. It is one of the nonparametric tests for which no prerequisites are needed (Mareš, Rabušic and Soukup, 2015; Landau, 2004).

In general, we can compile a table with expected data by recalculating the individual fields of the Pivot Table according to the formula (Elliott and Woodwart, 2007):

$$
n_{i j}=\frac{R_{i} S_{j}}{n}
$$

The recalculated expected values use the expected percentage of individual frequencies.

Suppose we should evaluate the intensity of the dependence of only one relation. In that case, the best interpretable coefficients are Phi $\varphi$ and Cramer's $V$ because they take values from the interval $[0,1]$. So, we can say whether the addiction is very weak - weaker - moderately strong - strong. Phi is defined by (Landau, 2004):

$$
\varphi=\sqrt{\frac{x^{2}}{n}}
$$

Cramer's $V$ is an extension of the above approach and is calculated as (Mareš, Rabušic and Soukup, 2015)

$$
V=\sqrt{\frac{x^{2}}{n d f^{*}}}
$$

Phi divided by the square root of $d f^{*}$. Thus, the guidelines are (Pallant, 2011):

\begin{tabular}{ccccc}
$d f^{*}$ & Small & Medium & Large \\
\hline 1 & .10 & .30 & .50 \\
\hline 2 & .07 & .21 & .35 \\
\hline 3 & .06 & .17 & .29 \\
\hline 4 & .05 & .15 & .25 \\
\hline 5 & .04 & .13 & .22 \\
\hline
\end{tabular}

Table 1: Effect sizes for Cramer's V (source: Pallant, 2011)

All calculations are performed in IBM SPSS Statistics according to the Řezanková (2017), Pallant (2011), Mareš, Rabušic and Soukup (2015), Landau (2004), Veres, Eva and Cavanagh (2020) and Elliott and Woodwart (2007).

\section{RESULTS}

The aim of the article is to compare the motivation for volunteering and volunteering experience with students of helping professions and economics. Three research hypotheses and two research questions were formulated and evaluated. They are interconnected and the answer to the research questions complement the verification of the hypotheses.

H1: There is no relationship between students' study program and their volunteering. In other words, the study programme and volunteering experience do not depend on each other.

H1 alternative: The study programme and volunteering experience depend on each other.

In our paper variable Field of Study is divided into two groups - "eco" as economic disciplines (Finance and Management, Travel and Tourism) and "non-eco" as helping professions (Clinical Social Worker, General Nurse and Midwifery). The variable Experience in volunteering is described by "yes" or "no". The following hypothesis will discuss the frequency of volunteering.

In our research, we want to find out whether the study programme depends on whether students have experience in volunteering or not. At first, the relationship between the two categorical variables was calculated using a contingency table (see Table 2). There was a total of 282 respondents, of which $143(50.7 \%)$ had no experience in volunteering and $139(49.3 \%)$ had some. $52.5 \%$ of students with positive experience were students of economics, while $49.3 \%$ were students of helping professions (non-economic disciplines). According to the Chi-Square test, we can decide on the dependence or independence. In this case, when the differences between the expected and observed frequencies are small, then we can say that the variables are independent. The $p$-value of the Chi-Square test was 0.148 (see Table 3) and at the significance level of 0.05 , we do not reject the null hypothesis about the independence of variables. The field of study and experience with volunteering do not depend on each other. 


\begin{tabular}{|c|c|c|c|c|}
\hline & & & \multicolumn{2}{|c|}{ Experience } \\
\hline & & & No & Yes \\
\hline \multirow{8}{*}{ Field of Study } & \multirow{4}{*}{ eco } & Count & 87 & 96 \\
\hline & & Expected Count & 92.8 & 90.2 \\
\hline & & $\%$ within Field of Study & $47.5 \%$ & $52.5 \%$ \\
\hline & & \% within Experience & $60.8 \%$ & $69.1 \%$ \\
\hline & \multirow{4}{*}{ non-eco } & Count & 56 & 43 \\
\hline & & Expected Count & 50.2 & 48.8 \\
\hline & & \% within Field of Study & $56.6 \%$ & $43.4 \%$ \\
\hline & & \% within Experience & $39.2 \%$ & $30.9 \%$ \\
\hline
\end{tabular}

Table 2: Field of Study * Experience Crosstabulation (source: own calculation)

\begin{tabular}{|c|c|c|c|c|c|}
\hline & Value & $d f$ & $\begin{array}{l}\text { Asymp. Sig. } \\
\text { (2-sided) }\end{array}$ & $\begin{array}{l}\text { Exact Sig. } \\
\text { (2-sided) }\end{array}$ & $\begin{array}{l}\text { Exact Sig. } \\
\text { (1-sided) }\end{array}$ \\
\hline Pearson Chi-Square & $2.093^{\mathrm{a}}$ & 1 & .148 & & \\
\hline Continuity Correction ${ }^{b}$ & 1.748 & 1 & .186 & & \\
\hline Likelihood Ratio & 2.098 & 1 & .147 & & \\
\hline Fisher's Exact Test & & & & .170 & .093 \\
\hline Linear-by-Linear Association & 2.086 & 1 & .149 & & \\
\hline $\mathrm{N}$ of Valid Cases & 282 & & & & \\
\hline
\end{tabular}

a. 0 cells $(0.0 \%)$ have expected count less than 5 . The minimum expected count is 48.80 .

b. Computed only for a $2 \times 2$ table.

Table 3: Chi-Square Tests (source: own calculation)

H2: There is no relationship between the study programme of college students and the frequency of volunteering. $\mathrm{H} 2$ alternative: The study programme of college students and the frequency of volunteering depend on each other.

Variable Frequency is described by numbers $0-4$ where 0 means no volunteering, $1=$ once a year, $2=$ once a half a year, $3=$ once a month and $4=$ once a week). We can see from Table 4 that the higher the frequency of students' volunteering is the fewer students are involved. There are small differences among the study programmes (see Table 4). For example, only $4.4 \%$ of economics students and on the other hand, $10.1 \%$ of helping profession students volunteer once a week. Then $18.6 \%$ of economics students and $8.1 \%$ of "non-eco" students volunteer once a half a year.

\begin{tabular}{|c|c|c|c|c|c|c|c|}
\hline & & & \multicolumn{5}{|c|}{ Frequency } \\
\hline & & & $0=$ no & 1 & 2 & 3 & $4=$ weekly \\
\hline \multirow{8}{*}{$\begin{array}{l}\text { Field of } \\
\text { Study }\end{array}$} & \multirow{4}{*}{ eco } & Count & 87 & 37 & 34 & 17 & 8 \\
\hline & & Expected Count & 92.8 & 33.7 & 27.3 & 17.5 & 11.7 \\
\hline & & $\%$ within Field of Study & $47.5 \%$ & $20.2 \%$ & $18.6 \%$ & $9.3 \%$ & $4.4 \%$ \\
\hline & & \% within Frequency & $60.8 \%$ & $71.2 \%$ & $81.0 \%$ & $63.0 \%$ & $44.4 \%$ \\
\hline & \multirow{4}{*}{ Non-eco } & Count & 56 & 15 & 8 & 10 & 10 \\
\hline & & Expected Count & 50.2 & 18.3 & 14.7 & 9.5 & 6.3 \\
\hline & & $\%$ within Field of Study & $56.6 \%$ & $15.2 \%$ & $8.1 \%$ & $10.1 \%$ & $10.1 \%$ \\
\hline & & $\%$ within Frequency & $39.2 \%$ & $28.8 \%$ & $19.0 \%$ & $37.0 \%$ & $55.6 \%$ \\
\hline
\end{tabular}

Table 4: Field of Study * Frequency Crosstabulation (source: own calculation)

\begin{tabular}{l|c|c|c} 
& Value & df & $\begin{array}{c}\text { Asymp. Sig. } \\
\text { (2-sided) }\end{array}$ \\
\hline Pearson Chi-Square & $10.029^{a}$ & 4 & .040 \\
\hline Likelihood Ratio & 10.358 & 4 & .035 \\
\hline N of Valid Cases & 282 & & \\
\hline
\end{tabular}

a. 0 cells $(0.0 \%)$ have expected count less than 5 . The minimum expected count is 6.32 .

Table 5: Chi-Square Tests (source: own calculation) 
In this case, when the differences between the expected and observed frequencies are big, then we can say that the variables are dependent. The $p$-value of the Chi-Square test was 0.040 (see Table 5) and at the significance level of 0.05 , we reject the null hypothesis about the independence of variables. The study programme and volunteering frequency depend on each other.

The strength of the dependence can be measured using the association coefficients. In our case, we used Cramer's $V$, where the $p$-value takes the value 0.189 (see Table 6). With degrees of freedom $d f=4$ (see Table 5), it can be deduced that the dependence between the variables field of study and frequency is moderately strong. It is closely related whether a student studies economic or uneconomic branch at the college and how often operates volunteering, closely related. This may be because, for example, the Clinical Social Worker and General Nurse programmes have a closer relationship to volunteering than the Tourism study programme.

\begin{tabular}{ll|c|c} 
& & Value & Approx. Sig. \\
\hline \multirow{2}{*}{$\begin{array}{l}\text { Nominal by } \\
\text { Nominal }\end{array}$} & Phi & .189 & .040 \\
\cline { 2 - 4 } & Cramer's V & .189 & .040 \\
\cline { 2 - 4 } & Contingency Coefficient & .185 & .040 \\
\hline \multirow{2}{*}{ N of Valid Cases } & 282 & \\
\hline
\end{tabular}

\section{Table 6: Symmetric Measures (source: own calculation)}

H3: The gender of students and the frequency of volunteering do not depend on each other.

$\mathrm{H} 3$ alternative: The gender of students and the frequency of volunteering depend on each other.

According to Table 7, 115 (50.9\%) out of 226 women and 28 $(50.0 \%)$ out of 56 men have never done volunteering. Only 1 man $(1.8 \%)$ and $17(14.4 \%)$ woman volunteer once a week.

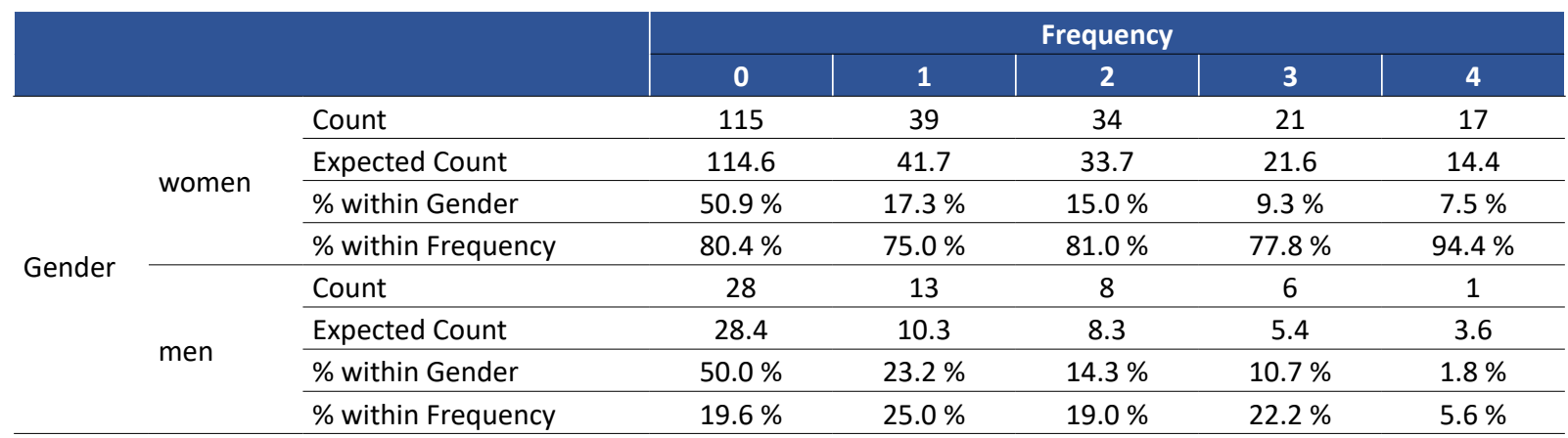

Table 7: Gender * Frequency Crosstabulation (source: own calculation)

The $p$-value of the Chi-Square test is 0.509 (see Table 8) and at the significance level of 0.05 , we do not reject the null hypothesis about the independence of variables. The gender and experience in volunteering do not depend on each other.

Beyond the hypothesis, we determined two research questions for better illustration of students' volunteering:
RQ1: What is the most frequently mentioned motivation for student volunteer activities?

RQ2: What is the most significant limitation for student volunteer activities?

\begin{tabular}{l|c|c|c} 
& Value & $d f$ & $\begin{array}{c}\text { Asymp. Sig. } \\
\text { (2-sided) }\end{array}$ \\
\hline Pearson Chi-Square & $3.297^{\mathrm{a}}$ & 4 & .509 \\
\hline Likelihood Ratio & 3.967 & 4 & .411 \\
\hline N of Valid Cases & 282 & & \\
\hline
\end{tabular}

a. 1 cells (10.0\%) have expected count less than 5. The minimum expected count is 3.57.

Table 8: Chi-Square Tests (source: own calculation)

\begin{tabular}{lc}
\multicolumn{1}{c}{ Motivation } & Number of students \\
\hline I feel useful & $67(48 \%)$ \\
\hline I will gain new experience and skills & $65(47 \%)$ \\
\hline I will use my skills & $4(3 \%)$ \\
\hline I make new friends & $2(1 \%)$ \\
\hline I want to fill my free time & $1(1 \%)$ \\
\hline Religious beliefs & $0(0 \%)$ \\
\hline I want to work in this area & $0(0 \%)$ \\
\hline Total & $139(100 \%)$ \\
\hline
\end{tabular}

Table 9: Motivations of students for volunteering (source: own calculation) 
From the results (see Table 9 and 10), students feel useful and gain new experience and skills when volunteering. The main reason for volunteer activities is not using their skills, making new friends or filling the free time. On the other hand, the students consider a lack of time and a lack of information to be the most significant limitations. The fact that volunteering is not paid does not seem to be a problem for students.

\begin{tabular}{lc}
\multicolumn{1}{c|}{ Limitation } & Number of students \\
\hline I do not have time & $72(50 \%)$ \\
\hline I would like to but I do not know how to get involved & $48(34 \%)$ \\
\hline Volunteering doesn't tell me anything & $12(8 \%)$ \\
\hline I do not want to. It's unpaid & $11(8 \%)$ \\
\hline Volunteers have a bad reputation & $0(0 \%)$ \\
\hline Total & $143(100 \%)$ \\
\hline
\end{tabular}

Table 10: Limitations of students for volunteering (source: own calculation)

Finally, students were asked if they were considering involvement in volunteer activities. Nobody answered "no, by no means". They said "yes" if they had more free time. Five students needed to be asked for volunteering.

\section{DISCUSSION}

Nowadays, students' volunteering is a trendy topic for articles (Bang, Won and Park, 2020; Young et al., 2020; Juliá-Sanchis, 2020; Dogan, 2020). But we state there is a lack of research about the comparison between students' volunteering in different study programmes. This finding was crucial for the decision to carry out our research. And it is not easy to describe the voluntary activities of students. The diversity of the student population is reflected in the variety in the engagement. Some students are involved in their local communities and their activity is not marked as student volunteering. The College of Polytechnics Jihlava is the only public institution of tertiary education in the Vysočina region. In general, communities, organisations, municipalities, and various associations rely on students' volunteer activities without precisely defined rules and understanding all aspects. It would be appropriate to develop a system for mapping students' volunteering.

Mlčák (2010) carried out a research to find out the differences in volunteering between students of assisting professions (in this case also pedagogical study programmes) and students of economic study programmes (national economy, regional development, financial journalism, etc.) at Technical University of Ostrava, Czech Republic. His respondents were only females. His research did not consider the number, the frequency and the length of volunteering activities and was more psychologically oriented. The students of assisting professions have richer experience with volunteering. The results of this research are, therefore, in conflict with the results of our survey. However, we must keep in mind that the basic files and methodology were not exactly the same. He found out statistically significant differences in the level of basic personality factors between these two groups of students. Students of assisting professions have a lower neuroticism level and a higher level of altruism, emotional behaviour, empathetic fantasy, etc. That is why we could concentrate more on economic students to increase their interest in volunteering.
Similar research was also realised at the University of South Bohemia in České Budějovice (Bezstarostiová, 2015). The author found out that $19 \%$ of students of Faculty of Economics (FE) and $54 \%$ students of the Faculty of Health and Social Sciences (FHSS) were active volunteers. The differences between the two groups of students (economic and uneconomic branch) were more significant in this research than in our survey $(52.5 \%$ and $49.3 \%)$. Most of them $(63 \%)$ are long-term volunteers. Most of the students of FHSS chose the field of education and worked with children and youth. Most of the students of FE worked as volunteers for communities. The most important motivational factor for both groups were social motives (strengthening of relationships). Chapman and Morleye (1999) and Fletcher and Major (2004) found out that women were more inclined to volunteer. Compared to that, Tomšů (2015) states that there is no difference between woman and men concerning volunteering. Also, according to our research, gender is not the determining factor.

The findings of the study from Barton, Bates and O'Donovan (2019) indicate that students were motivated to undertake voluntary extra-curricular work to give them a work-based experience that would enhance their prospects for both employment and post-graduate study. Students also discussed the impact this type of transformative and experiential learning had on their degree and their satisfaction whilst they were at their higher education institution. Febriani and Selamet (2020) emphasize the importance of brand image in increasing volunteering intention. The research by Joseph and Carolissen (2019) suggests that the desire to help others (value) and learning interpersonal skills (understanding) are core reasons for student volunteerism. The results of our survey are consistent with the stated outputs. The biggest motivation for volunteering is to feel useful, gain new experience and skills, use their skills, make new friends, fill free time, and work in this area. Another motive based on our research is a religious belief.

To limitations of the paper, our research was realised between 10/2019 and 3/2020, it means before pandemic of COVID-19. During this difficult period, volunteering was a significant part of our society (Nanavaty, 2020; Ludvigsen and Hayton, 2020; Cullum et al., 2020). It was necessary to sew masks, to help vulnerable group (seniors and people with health 
problems) with shopping. New research among students should be conducted after this crisis. Socialisation as a part of each organisation is also very important for corporate social responsibility (Glonti et al., 2020; Berei, 2020). Lachance (2020) provided another preview. A particular activity impacted by this pandemic is leisure. Within leisure, volunteering is an important activity to enhance social outcomes (e.g., civic participation) and the survival of organisations and events.

The situation associated with volunteering is changing not only in the Czech Republic, but also in other countries. Müllerová (2011) writes that volunteering is seen as something special, and that lack of information and little experience is the reason for not involving volunteers in organisations. Nowadays, most organisations working with volunteers have volunteer coordinators and approach their selection and management professionally and consciously rather than intuitively and randomly (Dostál et al., 2020). It follows that students have and will have more possibilities to find the best place for their volunteering on the one hand. And, on the other hand, their experience gained through volunteering will be more appreciated when looking for a job.

Volunteering as a manifestation of active citizenship naturally falls into the field of civic education (Palán and Langer, 2008). Ministry of Education, Youth and Sports in the Czech Republic (MŠMT, 2020) prepared an important document Strategy of the educational policy until the year $2030+$. It aims to define vision, priorities and goals of educational policy. One part is focused on the competencies needed for civic, professional and personal living. It can be assumed that volunteer activities will get more in mind as activities that enable the development of these competencies. Khasanzyanova (2017) writes that tertiary education does not provide all of the knowledge and skills required to succeed in modern society. Soft skills (personal and interpersonal skills) can be developed by volunteering and it is an important part of students' learning process and makes students' overall experience of higher education more relevant, active, and enjoyable. Volunteering is part of the so-called third role of universities. Each tertiary education institution approaches it a little differently. The only Volunteer centre founded by a university in the Czech Republic is operated by Palacky University Olomouc (Dobrovolnické centrum Univerzity Palackého, 2020).

Its activity consists of coordinating the volunteer activities of students and staff. The centre keeps a register of offers mainly from the given region, as well as records of already worked volunteer hours. Other colleges and universities were also very active in volunteering during the coronavirus pandemic emergency. However, the management of volunteer activities fell under various organisational units. This, of course, also implies a different degree of professionalism in coordinating current needs in society and the possibilities of helping students and employees. In the case, the vice-rector of studies led the volunteering. Not only the students of the fields which were the focus of attention in this article but also the others actively participated. Medical students were able to use their competencies and knowledge. They worked beyond their practices and working hours in hospitals and health and social care institutions. Technical students focused on $3 \mathrm{D}$ printing and helped with the production of protective shields. They also dealt with the diagnosis of potentially ill patients by monitoring with a thermal camera. Students of economics branches helped with purchases and with processing at the offices (VSPJ, 2020).

At present, however, there is practically a lack of summary information on how the academic sector provides organisational and financial support for its students' volunteer activities. The volume of volunteer work and its structure are not clear. According to studies of different authors and our results, competent persons of colleges should concentrate on students of the economic field of study to provide them an opportunity to participate in volunteering activities. Likewise, students do not have enough information and often do not even know how to get involved in these activities.

\section{CONCLUSION}

Volunteering, i.e., the willingness of a person to devote their time, energy, knowledge, knowledge, and skills to benefit other people or society without the right to remuneration, is a phenomenon experiencing a revival in our country in recent years. The article presents the research results into volunteering of 282 Czech students of economic and noneconomic study programmes of the College of Polytechnics Jihlava. According to the results, the field of study and frequency of volunteering depend on each other. The frequency of volunteering does not depend on the gender, not even the field of study and the experience with volunteering. The biggest motivations for volunteering are feeling useful and gaining new experience and skills. On the other hand, the lack of time and information (ignorance) are perceived as limitations. This study provides an opportunity for developing more guidelines in promoting volunteering activities within the young population and society as a whole.

For the future, as the importance of the online education is increasing (Kuncová and Vojáčková, 2015; Kostolányová, Šarmanová and Takács, 2012), we could suppose a growth of the online volunteerism (Alony et al., 2020; Şimon, 2019; Katsuragawa, Shu and Lank, 2019). Naqshbandi et al. (2020) studied the motivational drivers of the online volunteering. According to the authors, online environments help eliminate some of barriers. It provides the inclusion of marginalized demographics, who cannot participate in traditional forms of volunteering due to geographical, physical, or other barriers. On the other hand, online platforms can introduce new obstacles especially when the medium transforms the social interactions important to volunteers. Fukuzawa et al. (2020), Lee (2020) and Babb et al. (2020) lifted the importance of social network sites for volunteering because if we are talking about students' volunteering, the younger generation's widespread use of the online social network has raised. According to Lee (2020), these platforms can be useful tools for getting the word out and recruiting episodic volunteers. 
Alony, I., Haski-Leventhal, D., Lockstone-Binney, L., Holmes, K. and Meijs, L. C. (2020) 'Online volunteering at DigiVol: an innovative crowd-sourcing approach for heritage tourism artefacts preservation', Journal of Heritage Tourism, Vol. 15, No. 1, pp. 14-26. https://doi.org/10.1080/174387 3x.2018.1557665

Babb, S., McNaughton, D., Light, J., Caron, J., Wydner, K. and Jung, S. (2020) 'Using AAC video visual scene displays to increase participation and communication within a volunteer activity for adolescents with complex communication needs', Augmentative and Alternative Communication, Vol. 36, No. 1, pp. 31-42. https://doi.org/10.1080/07434618.2020.1737966

Bang, H., Won, D. and Park, S. (2020) 'School engagement, selfesteem, and depression of adolescents: The role of sport participation, volunteering activity, and gender differences', Children and Youth Services Review, Vol. 113, 105012. https:// doi.org/10.1016/j.childyouth.2020.105012

Barton, E., Bates, E. A. and O'Donovan, R. (2019) 'That extra sparkle': students' experiences of volunteering and the impact on satisfaction and employability in higher education', Journal of Further and Higher Education, Vol. 43, No. 4, pp. 453-466. https://doi.org/10.1080/0309877x.2017.1365827

Berei, E. B. (2020) 'The Social Responsibility among Higher Education Students', Education Sciences, Vol. 10, No. 3, pp. 66. https://doi.org/10.3390/educsci10030066

Bezstarostiová, L. (2015) Dobrovolnictvi a motivace $k$ němu $z$ pohledu studenti̊ Zdravotně sociálni fakulty a studentů Ekonomické fakulty, Jihočeská univerzita v Českých Budějovicích, Fakulta zdravotně sociální.

Bierhoff, H. W. (2006) Prosociální chování. In Hewstone, M. and Stroebe, W. (Eds.), Sociální psychologie, Prague: Portál.

Cullum, R. J., Shaughnessy, A., Mayat, N. Y. and Brown, M. E. (2020) 'Identity in lockdown: supporting primary care professional identity development in the COVID-19 generation', Education for Primary Care, Vol. 31, No. 4, pp. 1-5. https://doi.org/10.1080/14739879.2020.1779616

Cunha, J., Mensing, R. and Benneworth, P. (2019) 'A conceptual framework to understand student volunteerism', Tertiary education and management, Vol. 25, No. 1, pp. 31-44. https:// doi.org/10.3990/4.2589-9716.2018.03

Chapman, J., and Morley, R. (1999) 'Collegiate service-learning', Journal of Prevention \& Intervention in the Community, Vol. 18, No. 1-2, pp. 19-33. https://doi.org/10.1300/ j005v18n01 03

Dobrovolnické centrum Univerzity Palackého (2020) Dobrovolnictví v rámci mimořádných opatření proti šíreni Covid-19. [Online], Available: https://dobrovolnici.upol.cz/ [9 Jul 2020].

Dogan, P. (2020) 'Gender differences in volunteer's dilemma: Evidence from teamwork among graduate students', Journal of Behavioral and Experimental Economics, Vol. 84, 101488. https://doi.org/10.2139/ssrn.3316366

Dostál, J., Tošner, J., Černá, M., Činčalová, S., Závodný Pospíšil, J., Steinbauerová, R., Smrčka, F. and Musil, M. (2020) Ekonomická hodnota dobrovolnictví v teorii a praxi. Souhrnná výzkumná zpráva projektu Česko s dobrovolnictvím počítá, Vysoká škola polytechnická Jihlava.

Elliott, A. C. and Woodward, W. A. (2007) Statistical analysis quick reference guidebook: With SPSS examples, Sage.
Febriani, D. M. and Selamet, J. (2020) 'College Students' Intention to Volunteer for Non-profit Organisations: Does Brand Image Make a Difference?', Journal of Nonprofit \& Public Sector Marketing, Vol. 32, No. 2, pp. 166-188. https://doi.org/10.1080/10495142.2019.1656136

Fletcher, T. D. and Major, D. A. (2004) 'Medical students' motivations to volunteer: Anexamination of the nature of gender differences', Sex Roles, Vol. 51, pp. 109-114. https:// doi.org/10.1023/b:sers.0000032319.78926.54

Fukuzawa, A., Katagiri, K., Harada, K., Masumoto, K., Chogahara, M., Kondo, N. and Okada, S. (2020) 'Social networks as a factor in volunteering among elderly Japanese with lower socioeconomic status', Japanese Psychological Research, Vol. 62, No. 3, pp. 206-214. https://doi. org/10.1111/jpr.12249

Glonti, V., Trynchuk, V., Khovrak, I., Mokhonko, G., Shkrobot, M. and Manvelidze, L. (2020) 'Socialisation of Organization Sustainable Development Based on the Principles of Corporate Social Responsibility', Montenegrin Journal of Economics, Vol. 15, No. 1, pp. 169-182. https://doi. org/10.14254/1800-5845/2020.16-1.11

González, O. R., Yeste, C. G., Jiménez, J. M. and Ignatiou, Y. (2019) 'Student Teachers Volunteering in Pre-Service Programmes in Successful Schools: Contributing to Their Successful Training', Educación XX1, Vol. 22, No. 2, pp. 267-287. https://doi.org/10.5944/educxx1.22620

Haski-Leventhal, D., Oppenheimer, M., Holmes, K., LockstoneBinney, L., Alony, I. and Ong, F. (2019) 'The conceptualisation of volunteering among nonvolunteers: Using the net-cost approach to expand definitions and dimensions of volunteering', Nonprofit and Voluntary Sector Quarterly, Vol. 48, No. 2, pp. 30S-51S. https://doi.org/10.1177/0899764018768078

Haski-Leventhal, D., Paull, M., Young, S., MacCallum, J., Holmes, K., Omari, M. and Alony, I. (2020) 'The multidimensional benefits of University Student Volunteering: Psychological contract, expectations, and outcomes', Non-profit and Voluntary Sector Quarterly, Vol. 49, No. 1, pp. 113-133. https://doi.org/10.1177/0899764019863108

Joseph, B. M. and Carolissen, R. (2019) 'Citizenship: A core motive for South African university student volunteers', Education, Citizenship and Social Justice, Vol. 14, No. 3, pp. 225-240. https://doi.org/10.1177/1746197918792840

Juliá-Sanchis, R., Sanjuan-Quiles, A., Richart-Martínez, M. and Cabrero-García, J. (2020) 'The impact of volunteering in mental health settings on nursing students' attitudes', Nurse Education in Practice, Vol. 44, 102726. https://doi. org/10.1016/j.nepr.2020.102726

Katsuragawa, K., Shu, Q. and Lank, E. (2019) 'PledgeWork: Online volunteering through crowdwork' In Proceedings of the 2019 CHI Conference on Human Factors in Computing Systems, pp. 1-11. https://doi.org/10.1145/3290605.3300541

Khasanzyanova, A. (2017) 'How volunteering helps students to develop soft skills', International Review Education, Vol. 63, pp. 63-379. https://doi.org/10.1007/s11159-017-9645-2

Kogan, E. A. and Kvon, D. A. (2019) 'Studying the motives of volunteering among students', Perspectives of Science and Education, Vol. 40, No. 4, pp. 116-125. https://doi. org/10.32744/pse.2019.4.10 
Kostolányová, K., Šarmanová, J. and Takács, O. (2012) 'Adaptive e-learning and its evaluation', Journal on Efficiency and Responsibility in Education and Science, Vol. 5, No. 4, pp. 212-225 https://doi.org/10.7160/eriesj.2012.050404

Křivohlavý, J. (2003) Motivace sociální opory, In Mareš, J. a kol., Sociální opora u dětí a dospívajících III. Hradec Králové: Nucleus.

Kuncová, M. and Vojáčková, H. (2015) 'Analysis of the dependence of the e-learning usage on the study results', Journal on Efficiency and Responsibility in Education and Science, Vol. 8, No. 1, pp. 24-34 https://doi.org/10.7160/ eriesj.2015.080104

Lachance, E. L. (2020) 'COVID-19 and its Impact on Volunteering: Moving Towards Virtual Volunteering', Leisure Sciences, Vol. 43, No. 1-2, pp. 104-110. https://doi.org/10.1080/01490400. $\underline{2020.1773990}$

Landau, S. (2004) A handbook of statistical analyses using SPSS. CRC.

Lee, Y. J. (2020) 'Facebooking alone? Millennials' use of social network sites and volunteering', Nonprofit and Voluntary Sector Quarterly, Vol. 49, No. 1, pp. 203-217. https://doi. org/10.1177/0899764019868844

Lockstone-Binney, L., Holmes, K., Smith, K. and Baum, T. (2010) 'Volunteers and volunteering in leisure: Social science perspectives', Leisure Studies, Vol. 29, No. 4, pp. 435-455. https://doi.org/10.1080/02614367.2010.527357

Ludvigsen, J. A. L. and Hayton, J. W. (2020) 'Toward COVID-19 secure events: considerations for organising the safe resumption of major sporting events', Managing Sport and Leisure, pp. 1-11. https://doi.org/10.1080/23750472.2020.17 $\underline{82252}$

Mareš, P., Rabušic, L. and Soukup, P. (2015) Analysis of social data (not only) in SPSS. Brno: Masaryk University.

Mitic, R. R. (2020) 'Global Learning for Local Serving: Establishing the Links Between Study Abroad and Postcollege Volunteering', Research in Higher Education, Vol. 61, No. 5, pp. 603-627. https://doi.org/10.1007/s11162-02009604-w

Mlčák, Z. (2010) Prosociálni chováni v kontetu dispozičních aspektů osobnosti, Ostravská univerzita v Ostravě.

Moore, E., Warta, S. and Erichsen, K. (2014) 'College students' volunteering: Factors related to current volunteering, volunteer settings, and motives for volunteering', College Student Journal, Vol. 48, No. 3, pp. 386-396.

Moreno, M. A. (2013) 'Posttraumatic Stress in Children', JAMA pediatrics, Vol. 167, No. 12, 1176-1176. https://dx.doi. org/10.1001/jamapediatrics.2013.4238

Müllerová, M. (2011) Dobrovolníci pro kulturu: Dobrovolnická činnost $v$ kulturnich organizacich. Prague: Česká kancelář programu Culture.

Musick. M.A. and Wilson, J. (2008) Volnteers: A social profile. Bloomington: Indiana University Press.

Nanavaty, J. (2020) 'Volunteerism during COVID-19', Public Health Nursing, Vol. 37, No. 5, pp. 797-798. https://doi. org/10.1111/phn.12765

Naqshbandi, K. Z., Liu, C., Taylor, S., Lim, R., Ahmadpour, N. and Calvo, R. (2020) 'I Am Most Grateful. Using Gratitude to Improve the Sense of Relatedness and Motivation for Online Volunteerism', International Journal of Human-Computer Interaction, Vol. 36, No. 14, pp. 1325-1341. https://doi.org/1 $\underline{0.1080 / 10447318.2020 .1746061}$
Navickas, V., Simkus, A. and Strunz, H. (2016) 'The Impact of Volunteering as a Form of Leisure on Students' Life Quality', Transformations in Business \& Economics, Vol. 15, No. 3, pp. 96-112.

Osoba, P. (2017) 'Vliv vzdělání a životní spokojenosti na angažovanost obyvatel Česka', Naše společnost (Our Society), Vol. 2, No. 15, pp. $15-30$.

Palán, Z. and Langer, T. (2008) Základy andragogiky, Prague: Univerzita Jana Amose Komenského.

Pallant, J. (2011) SPSS Survival manual: a step by step guide to data analysis using SPSS, Crows Nest, New South Wales: Allen \& Unwin.

Pospíšilová, T., Frič, P. and Tošner, J. (2011) Volunteering Infrastructure in the Czech Republic: Situation - Trends-Outlook. [Online], Available: http://volunteertolearn.eu/files/2013/06/ Volunteering-Infrastructure-in-the-Czech-Republic -Situation Trends_Outlook CEV_ENG-2011.doc [5 Jul 2020].

Power, A., Boughen, A. and Ames, C. (2019) 'Out of Africa: Students' reflections on the personal and professional impact of volunteering', British Journal of Midwifery, Vol. 27, No. 1, pp. 59-61. https://doi.org/10.12968/bjom.2019.27.1.59

Rochester, C., Paine, A. E., Howlett, S. and Zimmeck, M. (2010) 'Making sense of volunteering: Perspectives, principles and definitions', In Volunteering and Society in the 21st Century, Palgrave Macmillan, London, pp. 9-23. https://doi. org/10.1057/9780230279438_2

Řezanková, H. (2017) Analysis of data from questionnaire surveys. Prague: Professional Publishing.

Savitz, D. A., Oxman, R. T., Metzger, K. B., Wallenstein, S., Stein, D., Moline, J. M. and Herbert, R. (2008) 'Epidemiologic research on man-made disasters: Strategies and implications of cohort definition for World Trade Center worker and volunteer surveillance program', Mount Sinai Journal of Medicine, Vol. 75, No. 2, pp. 77-87. https://doi.org/10.1002/msj.20023

Schech, S., Skelton, T., Mundkur, A. and Kothari, U. (2020) 'International Volunteerism and Capacity Development in Non-profit Organisations of the Global South', Nonprofit and Voluntary Sector Quarterly, Vol. 49, No. 2, pp. 252-271. https:// doi.org/10.1177/0899764019867774

Shier, M. L., Larsen-Halikowski, J. and Gouthro, S. (2020) 'Characteristics of volunteer motivation to mentor youth', Children and Youth Services Review, Vol. 111, 104885. https:// doi.org/10.1016/j.childyouth.2020.104885

Şimon, M. (2019) 'Volunteering for the Students in Brașov', Bulletin of the Transilvania University of Braşov, Series VII: Social Sciences and Law, Vol. 12(61), No. 1, pp. 139-146. https://doi. org/10.31926/but.ss1.2019.12.61.1.13

MŠMT (2020) Strategie vzdélávaci politiky ČR do roku 2030+ [Strategy of Educational Policy until the Year 2030+], Ministerstvo školství, mládeže a tělovýchovy České republiky [Online], Available: https://www.msmt.cz/vzdelavani/skolstvi-vcr/strategie-2030?lang=1 [1 Jul 2020].

Shye, S. (2010) 'The motivation to volunteer: A systemic quality of life theory', Social indicators research, Vol. 98, No. 2, pp. 183200. https://doi.org/10.1007/s11205-009-9545-3

Tomšů, B. (2015) Motivace dobrovolníků k dlouhodobému působeni ve vybrané neziskové organizaci, Brno: MU, FSS.

Veres, J. C., Eva, N. and Cavanagh, A. (2019) "'Dark" student volunteers: commitment, motivation, and leadership', Personnel Review, Vol. 49, No. 5, pp. 1176-1193. https://doi.org/10.1108/ pr-02-2019-0085 
VSPJ (2020) Vysoká škola polytechnická pomáhá $v$ boji $s$ koronavirem, [Online], Available: https://www.vspj.cz/skola/ obecne-informace/aktualita/1872 [2 Jul 2020].

Wilson, E. O. (2000) 'Volunteering', Annual Review of sociology, Vol. 26, No. 1, pp. 215 - 240. https://doi.org/10.1146/annurev. soc.26.1.215
Young, K. A., Willms, J., Culberson, J., Chavez, A., Zon, A., Patel, R. and Gassman, T. (2020) 'Development of a Premedical Student Volunteering/Mentorship Program Designed to Address the Economic Problem of the Caregiver-Patient Ratio in Skilled-Care Geriatric Memory Units', Journal of the American Geriatrics Society, Vol. 68, No. S1, pp. S138-S139.

\section{APPENDIX}

\section{QUESTIONNAIRE - VOLUNTEERING OF UNIVERSITY STUDENTS}

Dear students, in the following questionnaire we would like to ask you questions about volunteering. The questionnaire is anonymous and by filling it out you will contribute to the mapping of volunteer activities of VŠPJ students. Check one answer for each question. Thank you for your responsible approach to completing the questionnaire!

Ing. Simona Činčalová, Ph.D., Mgr. Martina Černá, Ph.D.

1. Gender:

$\square$ Female

$\square$ Male

2. Field of your study:

$\square$ Clinical Social Worker

$\square$ General Nurse, Midwifery

$\square$ Finance and Management

$\square$ Travel and Tourism

3. Do you have experience with volunteering?

$\square \quad$ Yes

$\square$ In case of the answer Yes, please follow questions 4,5 and 6

$\square$ No

$\square$ In case of the answer No, please follow questions 7 and 8

4. If you answered Yes to question 3, how often do you volunteer?

$\square$ once a week

$\square$ once a month

$\square$ once a half a year

$\square$ once a year
5. If you answered Yes to question 3, what motivates you to volunteer?

$\square \quad$ I feel useful

$\square \quad$ I will use my skills

$\square \quad$ I make new friends

$\square$ I will gain new experience and skills

$\square$ I want to keep fit / to fill my free time

$\square$ religious beliefs

$\square \quad$ I want to work in this area

other motivation:

6. If you answered Yes to question 3, when did you start volunteering?

$\square$ before studying at university

$\square$ during studying at university

7. If you answered No to question 3, why?

$\square \quad$ I do not have time

$\square \quad$ I do not want to, it's unpaid

$\square$ Volunteering doesn't tell me anything

$\square$ I would like to, but I do not know how to get involved

$\square$ Volunteers have a bad reputation

$\square$ anotheranswer:

8. If you answered No to question 3 , are you considering involvement in volunteer activities?

$\square \quad$ No, by no means

$\square$ Yes, only if someone close to me gets involved

$\square$ Yes, if anyone asks me to

$\square$ Yes, if I have more free time

$\square$ another answer: 